\title{
STUDENTS' EXPERIENCE OF LEARNING ESP: FINDINGS FROM A CASE STUDY IN LITHUANIA
}

\author{
Nijolè Burkšaitienè ${ }^{1}$, Jolita Šliogeriené2 \\ ${ }^{1}$ Vilnius University, Lithuania, E-Mail: nijole.burksaitiene@ flf.vu.lt \\ ${ }^{2}$ Vilnius Gediminas Technical University, Lithuania, jolita.sliogeriene@vgtu.lt
}

\begin{abstract}
This study explores undergraduate students' experience of learning English for Specific Purposes (ESP) and aims to reveal their views regarding university teachers' and peers' feedback provided to them during the course of ESP as well as to establish the students' views regarding their own learning ESP. The present article reports on the results of a case study from a Lithuanian university. The data were collected from feedback questionnaires of 111 students in 11 study programmes. To analyse the data, quantitative methodology was used. The main conclusion of the present study is that most study participants viewed their own learning ESP at the university as a positive experience, i.e. the students were satisfied with their engagement in learning this study subject and considered that learning was aligned with teaching and assessment. The results of the study also demonstrated that the study participants considered that collaboration and team work fostered meaningful learning, as well as that peer feedback helped them to understand how to improve in learning ESP. It was established that students valued their teachers' patience and personal engagement and that the teachers' feedback improved the ways of learning ESP, encouraged them to think and analyse the content of the study material, and helped them to clarify things they did not understand learning on their own.
\end{abstract}

Key words: students' experience, ESP studies, teachers' feedback, peers' feedback, views regarding learning ESP, higher education

\section{INTRODUCTION}

To ensure teaching for enhanced learning in higher education environment, new methodologies of teaching and learning (e.g. problem-solving, project-based, portfoliobased teaching and learning, collaborative learning, technology-enhanced learning, webassisted learning) and assessment (portfolio assessment, self and peer assessment) have been increasingly adopted by higher education institutions across the globe. These innovations have been widely researched, e.g. students' experience of learning, their approaches to learning and the relationship between learning and their approaches to it have been investigated, students' views regarding teaching and assessment have been analysed, the impact of teaching and assessment practices on students' learning, achievement and self-regulation has been analysed, as well as the impact of feedback on student learning has been studied in a number fields of study, including teacher education, engineering, business and medical education, and the studies of English (Ramsden, 1987, 2003; Rydel, 1987; Gibbs, 1999; Biggs, 2006; Carrington and Selva, 2010; Fernandes, Flores and Lima, 2012; Ezer, Gilat and Sagee, 2010; Harrison and Gibbons, 2013; Lina and Wangb, 2018; Kavaliauskiené, Kaminskienė and Anusienè, 
2007; Šliogerienè, 2016, 2013; Burkšaitienè and Teresevičienė, 2008; Burkšaitienè, 2012; Lam, 2013; Allen, 2015; Buzzetto-More, 2015; Black and William, 1998; Brown, 2001; Knight, 2001; Hattie and Timperley, 2007; Tummons, 2007; Paulos and Mahony, 2008; Nicol and Macfarlane-Dick, 2006; Liu and Carless, 2006; Price et al, 2011).

It is reported in the literature that to enhance student learning in higher education, teaching and learning should be analysed using a relational perspective, which involves inquiry into and reflection on how students learn a specific subject matter in particular contexts (Biggs, 1987: 275). It was established that to foster quality learning, it is crucial to understand students' experiences of learning, that teaching, learning and assessment should be conceived in such a way that they provide students with some opportunities to foster their ability to question, deconstruct and reconstruct knowledge (Gibbs, 1999; Ramsden, 2003; Leonardo, 2004, cited in Carrington and Selva, 2010; McDowell et al, 2011; Fernandes et al, 2012; Sánchez et al., 2008). The research also demonstrated that learning is significantly fostered in active higher educational environments, i.e. in the environments where students are provided with feedback which enables them to actively engage in the process of learning, which is aimed to develop learning and enhance students' self-regulation of learning (Hattie and Timperley, 2007; Tummons, 2007; Brown, 2001; Black and William, 1998; Knight, 2001; Paulos and Mahony, 2008; Nicol and Macfarlane-Dick, 2006; Liu and Carless, 2006; Price et al, 2011; Burkšaitienè, 2012; Burkšaitienė and Stojković, 2016; Šliogerienè, 2012).

Even though the research on students' views regarding learning in the university environment is extensive, in Lithuania studies aimed to elicit students' perspectives and experiences of learning English for Specific Purposes (ESP) have been scarce (Suchanova, Mockienè, Šliogerienè, 2017; Burkšaitienė and Teresevičienè, 2008; Kavaliauskienė, Kaminskienė and Anusienė, 2007). Therefore, to explore undergraduate students' experience of learning this particular study subject, we analysed their views when they became novice learners at a university in Lithuania.

The present research was conducted with the participation of 111 students who studied ESP in 11 undergraduate study programmes. The study aimed to address the following research questions: (1) what were the students' views regarding their peers' feedback provided to them during the course of ESP? (2) what were the students' views regarding their teachers' feedback provided to them during the course? and (3) what were the students' views regarding their own learning ESP at the university?

The data for the present research were collected from the structured questionnaires that the study participants received and filled in after the course of ESP. All student responses were given on a voluntary basis and were held anonymous. The present study begins with the description of the theoretical background which is followed by the explanation of the research methodology and the research limitation. The results of the study are then presented, and the conclusions drawn. To carry out the research, quantitative methodology was used.

\section{THEORETICAL BACKGROUND}

To understand the complex process of teaching, learning and assessment in higher education environment, perception theory is important. According to this theory, perception is a process through which knowledge of the objective world is acquired 
(Maund, 2003), therefore it can reveal how the process participants perceive the interaction. More importantly, the knowledge of such an interaction can be used to organise teaching for enhanced learning. This is in line with the socio-constructive perspectives on student learning and its basic assumptions, including the assumption that teaching and learning are interactive, that learning is aimed at understanding, therefore knowledge cannot be imposed or transmitted to students by direct instruction, and that feedback can be used as a powerful tool for enhanced learning (Biggs, 1999; Hattie and Timperley, 2007; Price et al, 2011). In his work, Biggs (1999) stressed that according to the theory of constructivism, learning is a way of interacting with the world which results in a change of learners' conceptions of the world and its phenomena, therefore, by analysing this interaction it is possible to understand how teaching should be designed so that it enhances learning. A possible solution, suggested by Biggs (1999), is creating aligned teaching systems where all components, including curricula objectives, teaching/learning activities and assessment tasks, are constructively aligned.

It is reported in the literature that to foster students' learning, it is crucial to understand how they learn, i.e. what concepts of learning they adopt. The literature shows that students' concepts of learning fall into two major categories, including those regarding learning as a process of memorisation and reproduction of information and those regarding learning as an interpretative process aimed at understanding the meaning and integrating present learning with the previous learning experience (Hargreaves, 1997, cited in Fernandes et al, 2012; Willis, 2003, cited in Fernandes et al, 2012). Discussing the ways how students learn, Biggs (1999) and Ramsden (2003) described two approaches to learning that students can adopt, including a surface approach and a deep approach. Biggs (1999) defined the concept of an approach to learning as learning activities that the students use to fulfil a task, thus a surface approach refers to activities of a low cognitive level, which result in fragmented outcomes of learning. More specifically, surface learning results in remembering facts and not interpreting or understanding the meaning behind them. A deep approach to learning, on the other hand, is learning which is seeing the whole picture, understanding the relationships between facts and the meaning behind them (Biggs, 1999: 59-60; Ramsden, 2003). Therefore, in order to design teaching which leads students to deep learning, it is important to understand which approach they use while studying a particular subject, if they share the same approach to learning, and why they choose a particular approach.

The literature overview reveals that feedback plays a significant role for the enhancement of learning. Nowadays, feedback is firmly embedded within higher education systems and serves a wide range of purposes. For example, it can be given only for error correction or it can be used to promote student learning through identifying a gap between one's performance and the expected standard or it can be given to develop students' self-evaluative capabilities (Sadler, 1989, in Price et al, 2011: 880; Hettie and Timperley, 2007; Nicol and Macfarlane-Dick, 2006).

Depending upon who it is generated by, feedback falls into two main types - internal feedback and external feedback. The former type of feedback is generated by learners themselves at a variety of levels (including cognitive, behavioural and motivational) by reflecting on learning and assessing it. External feedback, on the other hand, is provided to students by their teachers and peers, placement officials, etc. External feedback provided by teachers contains information regarding students' performance or understanding. It typically occurs after the instruction and becomes a source against 
which students can evaluate progress, check their internal gaols, criteria and standards (Hattie and Timperley, 2007). Peer feedback is information provided to students by other students and relates to the communication process through which learners enter into dialogues related to performance and standards (Liu and Carless, 2006: 281).

It is established by research that external feedback used for formative assessment improves students' learning, maintains sustainable learning and produces significant learning gains if it is effective. In the literature, varied characteristic features have been attributed to effective feedback and some of them have been established to be repeatedly used by researchers to define effective feedback. Thus, to be effective, feedback has to be clear, understandable, purposeful, motivating, compatible with students' prior knowledge, providing links to the gaps in their learning that have to be closed, engaging, and compatible with the modes of receiving feedback (Tummons, 2007; Brown, 2001; Black and William, 1998; Knight, 2001; Paulos and Mahony, 2008; Nicol and Macfarlane-Dick, 2006; Liu and Carless, 2006).

In their research, Hattie and Timperley (2007) stressed that feedback has the most powerful impact on students' leaning when they answer the main three questions asked by the teacher: "Where am I going?" ("Feed up"), "How am I going?" ("Feed back") and "Where to next?" ("Feed forward") on the level of task, process, self-regulation and self. The researchers concluded that answering the last question is crucial as it leads students to more strategies and processes to work on a task, to more self-regulation and deeper understanding of the gaps in one's learning that have to be closed. Similarly, in the research conducted by Price et al (2011) on students' engagement with assessment feedback it is stressed that in higher education assessment feedback should be used as a long-term dialogic process between teachers and students. The authors state that such a dialogue enables students to use assessment feedback to develop their learning rather than respond mechanistically to their teachers' instruction.

To sum up, the research demonstrates that whatever the purpose, feedback has the power to enhance learning and to lead students to further improvements in learning and better achievements in the future when it serves to develop students' understanding of the subject and what high quality performance is.

\section{THE RESEARCH METHODOLOGY}

The conceptual rationale to investigate students' experience of learning ESP at the university from the student perspective is based primarily on the theory of perception and its central assumption that perception is a process through which knowledge of the objective world is acquired (Maund, 2003). Therefore, by analysing this process it can be revealed how its participants perceive the interaction, and the knowledge of this can be used to organise teaching ESP for enhanced learning. The present research is also drawing on the socio-constructive perspectives of learning, as exemplified in the works of Biggs (1999) and Ramsden (2003), i.e. that learning is a way of interacting with the world which results in a change of learners' conceptions of the world and its phenomena. Therefore, by analysing this interaction it is possible to understand how to enhance learning ESP. Implicit in this approach are the two key assumptions, i.e. that students are active participants in the process of learning, which enables them to construct meanings 
of learning, and that feedback provided to students by their teachers and peers is aimed to enhance learning.

To gain insights into undergraduate students' experience of learning ESP at a university in Lithuania, a quantitative study was conducted and students' views were investigated. The data were collected through the structured feedback questionnaires that were filled in by the students at the end of the course of ESP and analysed using the Statistical Package for Social Sciences (SPSS version 22).

\subsection{The context of the study}

The present paper reports on the results of a quantitative study conducted at a university in Lithuania with the participation of 111 undergraduate first-year students (35 males and 74 females) who studied English for Specific Purposes in 11 study programmes (Table 1).

Table 1 Study programme and gender crosstabulation

\begin{tabular}{|c|c|c|c|c|c|}
\hline & \multicolumn{3}{|c|}{ Gender } & \multirow[b]{2}{*}{ Total } \\
\hline & & Female & Male & no answer & \\
\hline \multirow{11}{*}{$\begin{array}{l}\text { Study } \\
\text { programme }\end{array}$} & Tourism management & 2 & 3 & 0 & 5 \\
\hline & Law and Customs & 24 & 9 & 0 & 33 \\
\hline & Law & 7 & 9 & 0 & 16 \\
\hline & International Business & 6 & 7 & 0 & 13 \\
\hline & Public Administration & 8 & 3 & 0 & 11 \\
\hline & Psychology & 7 & 1 & 0 & 8 \\
\hline & ESP and the $2^{\text {nd }}$ foreign language & 6 & 0 & 0 & 6 \\
\hline & International Communication & 9 & 1 & 0 & 10 \\
\hline & Public Policy & 2 & 2 & 0 & 4 \\
\hline & Social Work & 3 & 0 & 0 & 3 \\
\hline & No answer & 0 & 0 & 2 & 2 \\
\hline \multicolumn{2}{|l|}{ Total } & 74 & 35 & 2 & 111 \\
\hline
\end{tabular}

At the university, the course of ESP was mandatory in all undergraduate study programmes and was scheduled for the first year of studies. The course consisted of 128 academic hours ( 6 credits), which included practical classes held four times / 8 academic hours a week. In all study programmes the students studied ESP for one semester, at the end of which they were asked to fill in feedback questionnaires. None of the research participants had studied ESP before they started this course at the university.

The instrument used for the present study was a structured feedback questionnaire which included four sections, i.e. a section on demographic data and three sections of statements that focused on the students' views regarding (1) their peers' feedback provided during the course of ESP, (2) the teachers' feedback provided to them during the course of ESP, and the statements aimed to investigate the students' views regarding their own learning ESP.

The limitation of the present study is that it was conducted in one Lithuanian university where ESP is a mandatory study subject in all undergraduate study 
programmes, which does not allow for generalisations on the scale of Lithuanian higher education.

\subsection{Data analysis}

The data collected through the structured feedback questionnaires were analysed using the Likert-type scale of measurement, i.e. a five-point scale of agreement ranging from "strongly agree" to "strongly disagree", and statistical data analyses, including the analysis of variance (ANOVA), the statistical analysis for the estimation of correlation between variables (Pearson and Spearman correlation) and Bonferroni post hoc criterion.

To establish the consistency of the questions for the sample, Cronbach alpha coefficient was used, and a high level of internal consistency was established (Cronbach alpha $=0.91$ ). The participants' demographic data regarding their gender and the study programme were excluded from the calculation as they did not have internal correlation with or significance on the research results.

\section{RESEARCH RESULTS}

To analyse undergraduate students' experience of studying ESP at the university, their responses to three groups of statements were studied. The first group of statements aimed to investigate the students' views regarding their peers' feedback provided to them during the course. It included the following statements: "Working with other students helped me to judge how my own learning was going", "Working with other students helped me to develop my understanding", "Students supported each other and tried to give help when it was needed", "I was given plenty of opportunities to develop my skills in the subject", and "On this study subject I was prompted to think about how well I was learning and how I might improve".

The research results revealed that peer-provided support was very much appreciated during the learning process, i.e. a statistically significant correlation of medium strength was found between the variables "Working with other students helped me to judge how my own learning was going" and "Working with other students helped me to develop my own understanding" $\left(r=0.500^{* *}, p=0.000\right)$, indicating that the more they collaborated during the course of ESP and judged how they were learning, the better they understood the meaning of what they were learning. Also, a weak but statistically significant correlation was established between the variables "Working with other students helped me to develop my own understanding" and "Students supported each other and tried to give help when it was needed" ( $\left.r=0.311^{* *}, p=0.000\right)$, indicating that the more they collaborated during the course of ESP and understood what they were learning, the more they supported each other when it was necessary. These findings allow to assume that collaboration and team work were perceived by the students as leading them to meaningful learning.

The analysis of variance (ANOVA) showed statistical significance of differences $(F=$ 5,914; $p=0.001$ ) between the variables falling under the group of statements - students' views towards peer-provided feedback: "Working with other students helped me to judge 
how my own learning was going" and "I was given plenty of opportunities to develop my skills in the subject". The respondents stated that they supported each other and tried to help each other when it was needed, which enhanced their opportunities to develop ESP skills. This finding was also supported by Bonferroni post hoc criterion calculation which tabulated a significant relation, the dependent variable being "student support" ( $p=$ 0.002).

ANOVA calculation also revealed a statistically significant relation between the variables "Working with other students helped to develop my understanding" and "On this study subject I was prompted how to improve" $(F=6,333, p=0.000)$. These findings indicated that the students' views regarding their peer-provided feedback were positive, that peer feedback promoted thinking about their own learning and checking their own internal goals. The respondents confirmed that collaboration with other students helped them to develop their understanding and prompted how to improve in learning ESP.

The second group of statements encompassed variables focused on the students' views regarding their teacher-provided feedback on learning ESP: "Staff tried to share their enthusiasm about the subject with us", "In this course I was given plenty of opportunities to test out ideas and ways of thinking about the subject", "Staff were patient in explaining things which seemed difficult to grasp", "The feedback given on my work during this course helped me to improve my ways of learning and studying", "The feedback given on my work during the course helped to clarify things I hadn't fully understood", "I was encouraged to rethink my understanding of some aspects of the subject", and "It was clear to me what was expected in the assessed work for this subject".

The results of the study showed the following statistically significant correlations: a weak but statistically significant correlation between the variables "Staff were patient in explaining things which seemed difficult to grasp" and "The feedback given on my work during this course helped me to improve my ways of learning and studying" ( $r=0.330$ **, $p=0.000$ ) as well as between "Staff tried to share their enthusiasm about the subject with us" and "I was encouraged to rethink my understanding of some aspects of the subject" ( $r=0.299 * *, p=0.001 *)$. The former finding indicated that the more patient the teachers were while helping the students to cope with difficulties arising while learning ESP, the more feedback improved the students' ways of learning this study subject. The latter finding indicated that the more teachers were personally engaged in teaching ESP, the more they encouraged their students to think about this study subject.

Some other findings revealing the importance of teacher-provided feedback during the course of ESP are presented in Table 2. 
Table 2 The importance of teachers' feedback in understanding the subject

\begin{tabular}{|l|l|r|r|r|r|c|}
\hline \multicolumn{2}{|c|}{} & Sum of Squares & df & Mean Square & F & Sig. \\
\hline Understand to get & Between Groups & 2,182 & 4 &, 545 &, 541 &, 706 \\
good marks & Within Groups & 106,900 & 106 & 1,008 & & \\
\cline { 2 - 8 } & Total & 109,081 & 110 & & & \\
\hline Helped to improve & Between Groups & 19,759 & 4 & 4,940 & 9,941 &, 000 \\
& Within Groups & 52,674 & 106 &, 497 & & \\
\cline { 2 - 9 } & Total & 72,432 & 110 & & & \\
\hline Encouraged to rethink & Between Groups & 13,704 & 4 & 3,426 & 8,028 &, 000 \\
& Within Groups & 45,233 & 106 &, 427 & & \\
\cline { 2 - 9 } & Total & 58,937 & 110 & & & \\
\hline \multirow{2}{*}{ What was expected } & Between Groups & 7,894 & 4 & 1,974 & 4,856 &, 001 \\
& Within Groups & 43,079 & 106 &, 406 & & \\
\cline { 2 - 8 } & Total & 50,973 & 110 & & & \\
\hline
\end{tabular}

For example, the findings demonstrate that statistical significance of differences was determined between the importance of feedback and improving the students' understanding of ESP studies $(F=9,941 ; p=0.000)$. Also, the respondents admitted that teacher-provided feedback throughout the course encouraged them to rethink and analyse the content of the study material repetitively: "The teaching encouraged me to rethink my understanding of some aspects of the subject" $(F=8,028 ; p=0.000)$ and that it was clear to them "what was expected in the assessed work for this subject" $(F=4,856 ; p=0.001)$.

Besides, the research findings indicated that the $67 \%$ of the respondents expressed positive views regarding their experience of learning ESP and emphasised their teachers' support. Statistical significance of differences was determined between the variables of "It was clear to me what was expected in the assessed work for this subject" and "Staff tried to share their enthusiasm about the subject with us" $(F=8,126 ; p=0.000)$ as well as "Throughout this course I was encouraged to think how best to tackle the set work" $(F=$ 9,173; $p=0.000$ ), indicating that the students' view regarding their experience of learning ESP was highly positive. It was also established that $74 \%$ of the students agreed that their teachers' support helped them to improve ESP skills and that it was the support which they needed to think how to approach the set work for this subject.

The third group of statements aimed to establish the students' views regarding their own learning ESP. It included the following statements: "I enjoyed being involved in this subject", "This subject encouraged me to relate what I learned to issues in the wider world", and "This subject seemed to be more about learning than jumping through assessment". Having analysed the students' responses in terms of a possibility to reflect on what they have been learning and their attitudes towards it, it was established (Chart 1 , 


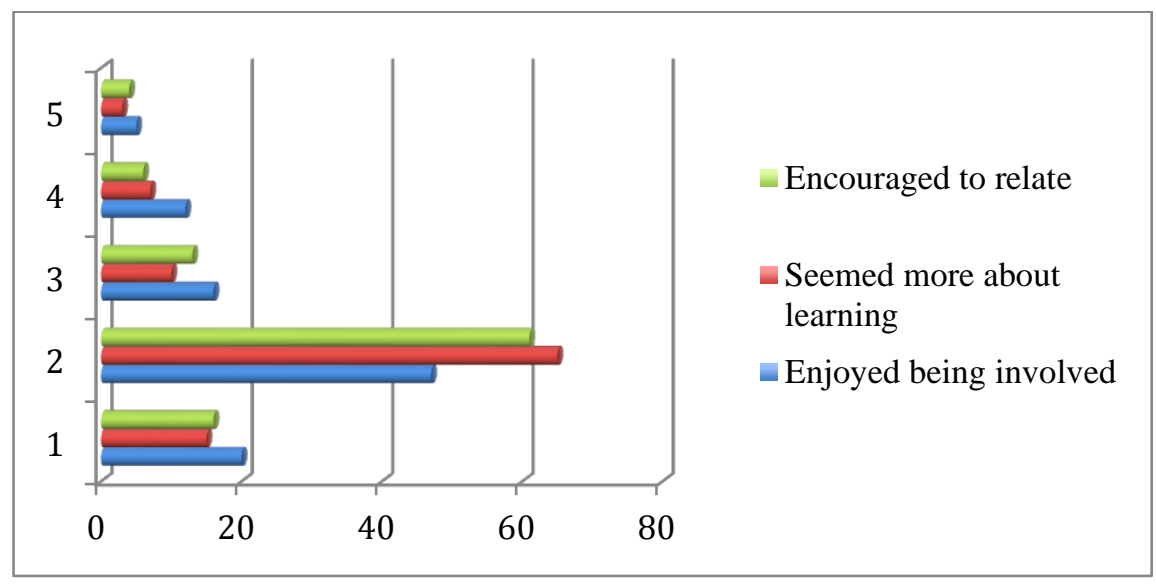

Chart 1 Students' views regarding their own learning ESP

where 1- strongly agree, 5 - strongly disagree) that the majority of the respondents either strongly agreed or agreed with the statements. To illustrate, $75 \%$ of students admitted that learning ESP "encouraged them to relate what they learned to issues in the wider world", indicating that during the course the students' new knowledge in ESP was created within a wide context. Besides, $80 \%$ of the respondents said that "This subject seemed to be more about learning than jumping through assessment", which allows to assume that learning was aligned with teaching and assessment. It was also established that $67 \%$ of the students expressed their satisfaction with having been involved in ESP subject, which indicates that their experience of learning ESP was positive.

Thus, the research results indicate that the students' positive views regarding learning ESP (as expressed in their responses) reflect their positive experience, which helped them to understand the study subject and what high quality performance is.

\section{CONCLUSIONS}

To enhance learning, it is of vital importance to understand students' experience of learning (Bigg, 1999; Ramsden, 2003), therefore, the present study aimed to address three research questions: 1) what were the students' views regarding their peers' feedback provided to them during the course of ESP? (2) what were the students' views regarding their teachers' feedback provided to them during the course of ESP? and (3) what were the students' views regarding their own learning ESP at the university?

The main conclusion of the present study is that most study participants viewed learning ESP at the university as a positive experience, i.e. the students were satisfied with their engagement in learning this study subject and considered that learning was aligned with teaching and assessment. These results are in accord with Biggs (1999) who emphasised that creating aligned teaching systems where all components, including curricula objectives, teaching/learning activities and assessment tasks, are constructively aligned is a prerequisite of enhanced learning in higher education. More specifically, the results showed that the students perceived that during the course of ESP they were 
encouraged to link what they learnt to issues in the wider world. This corroborates the findings of the researchers who stated that to promote quality learning, teaching, learning and assessment should be conceived in such a way that they provide students with some opportunities to foster their ability to question, deconstruct and reconstruct knowledge (Gibbs, 1999; Ramsden, 2003; Leonardo, 2004, cited in Carrington and Selva, 2010; McDowell et al, 2011; Fernandes et al, 2012; Sánchez et al., 2008).

The results of the study showed that the students viewed that their peers' feedback provided to them during the course of ESP prompted to them how to improve in learning ESP, which is in accord with Sadler $(1989$, cited in Price et al, 2011) who stated that feedback can promote student learning through identifying a gap between one's performance and the expected standard. Besides, the results showed that the students considered that collaboration fostered their understanding of what was being learnt, and that peer-provided feedback was viewed as the support which was provided at the right time, i.e. when it was the most necessary. These findings are in accord with Liu and Carless (2006) who considered that peer feedback acts as a communication process through which learners enter into dialogues related to performance and standards and allow to conclude that collaboration and team work were perceived as fostering meaningful learning.

This study also revealed how the students perceived their teachers' feedback provided to them during the course of ESP. It was established that they valued their teachers' patience and personal engagement. The results also showed that when provided to cope with difficulties arising while learning ESP, the teachers' feedback improved the study participants' ways of learning this study subject. More specifically, the findings revealed that the teachers' feedback encouraged the students to think and analyse the content of the study material and helped them to clarify things they did not understand while learning on their own. These findings are in line with Lea and Street (1998, cited by Price et al, 2010) who stressed that feedback in higher education must be concerned with developing new ways of knowing.

The results of the present study contribute to this field of research by providing a deeper insight on how the students themselves view their own learning ESP at the university and how they perceive their peer- and teacher-provided feedback, which are prerequisites of active engagement for enhanced learning within academia.

\section{REFERENCES}

Allen, Christopher. 2015. "Social media as an alternative to Moodle in EFL teaching practice forums". F. Helm, L. Bradley, M. Guarda, \& S. Thouesny (Eds.), Critical CALL Proceedings of the 2015 EUROCALL Conference, Padova, Italy (9-15). Dublin: Research-publishing.net. http://dx.doi.org/10.14705/rpnet.2015.000303.

Biggs, John. 1999. "What student does: teaching for enhanced learning". Higher Education Research and Development 18 (1): 57-75. Accessed February 16, 2012. Doi: 10. 1080/0729436990180105.

Black, Peter, and William, Dylan. 1998. "Inside the black box: raising standards through classroom assessment". Phi Delta Kappan 80 (2): 139-148.

Brown, George. 2001. Assessment: A Guide for Lecturers. York: Learning and Teaching Support Network Generic Centre. 
Burkšaitienè, Nijolè. 2012. "Peer feedback for fostering students' metacognitive skills of thinking about learning in a course of English for law". Societal Studies 4 (4): 1341-1355.

Burkšaitienè, Nijolè, and Stojković, Nadežda. 2016. "Students' reflections in a course of modern English and creative writing: a path to self-regulated learning". Kalba ir kontekstai / Language in Different Contexts 7 (1) Part 2: 212-225.

Burkšaitienè, Nijolè, and Teresevičienè, Margarita. 2008. "Integrating alternative learning and assessment in a course of English for law students". Assessment \& Evaluation in Higher Education 33 (2): 155-166.

Buzzetto-More, Nicole. 2015. "Student attitudes towards the integration of YouTube in online hybrid and web-assisted course: an examination of the impact of course modality on perception". MERLOT Journal of Online Learning and Teaching 11 (1): 55-73.

Carrington, Suzanne, and Selva, Gitta. 2010. "Critical social theory and transformative learning: evidence in pre-service teachers' service-learning reflection logs". Higher Education Research \& Development 29 (1): 45-57.

Ezer, Hanna, Gilat, Izhak, and Sagee, Rachel. 2010. "Perception of teacher education and professional identity among novice teachers". European Journal of Teacher Education 33 (4): 391-404.

Fernandes, Sandra, Flores Maria, and Lima, Rui Manuel. 2012. "Students' views regardingassessment in project-led engineering education: findings from a case study in Portugal". Assessment \& Evaluation in Higher Education 37 (2): 163-178.

Gibbs, Graham. 1999. "Using assessment strategically to change the way students learn". $S$. Brown, \& A. Glasner (Eds.), Assessment Matters in Higher Education: Choosing and Using Diverse Approaches. Maidenhead: SRHE / Open University Press.

Hattie, John, and Timperley, Helen. 2007. "The Power of feedback". Review of Educational Research 77 (1): 81-112. Accessed August 12, 2018. https://doi.org/10.3102/003465 430298487.

Kavaliauskienè, Galina, Kaminskienė, Ligija, and Anusienè, Lilija. 2007. "Reflective practice: assessment of assignments in English for Specific Purposes". Ibérica 14: 149-166. Accessed August 15, 2018. http://www.aelfe.org/documents/14-08_galina.pdf.

Knight, Peter. 2001. A Briefing on Key Concepts: Formative and Summative, Criterion and Norm-referenced Assessment. Assessment Series 7. York: Learning and Teaching Support Network Generic Centre.

Lam, Ricky. 2013. “Two portfolio systems: EFL students' perceptions of writing ability, text improvement, and feedback". Assessing Writing 18: 132-153.

Lina, Yu-Ju, and Wangb, Hung-Chun. 2018. "Using enhanced OER videos to facilitate English L2 learners' multicultural competence". Computers \& Education 125: 74-85. Accessed August 15, 2018. Doi: 10.1016/j.compedu.2018.06.005.

Liu, Ngar-Fun, and Carless, David. 2006. "Peer feedback: the learning element of peer assessment". Teaching in Higher Education 11 (3 July): 279-290. Accessed August 15, 2018. http://davidcarless.edu.hku.hk/wp-content/uploads/2006_Peer-feedback-Thelearning-element-of-peer-assessment.pdf.

Maund, Barry. 2003. Perceptions. (Philosophy). Chesham: Acumen. Accessed June 15, 2012.

http://site.ebrary.com.skaitykla.mruni.eu/lib/mrulibrary/reader.action?docID=10455609\& ppg=1.

McDowell, Liz, Wakelin, Delia, Montgomery, Catherine, and King, Sara. 2011. "Does assessment for learning make a difference? The development of a questionnaire to explore the student response". Assessment \& Evaluation in Higher Education 36 (7): 749-765. Accessed August 12, 2018. Doi: 10.1080/02602938.2010.488792. 
Nicol, David, and Macfarlane-Dick, Debra. Rethinking Formative Assessment: A Theoretical Model and Seven Principles of Good Feedback Practice. Enhancing Student Learning Through Effective Formative Feedback. York: The Higher Education Academy Generic Centre. Accessed June 24, 2011. http://www.heacademy. ac.uk/assets/documents/resources/resourcedatabase/id353_senlef_guide.pdf.

Price, Margaret, Handley, Kare, and Millar, Jill. 2011. "Feedback: focusing on engagement". Studies in Higher Education 36 (8): 879-896.

Ramsden, Paul. 1987. "Improving teaching and learning in higher education: the case for a relational perspective". Studies in Higher Education 12 (3): 275-286. Accessed April 18, 2012. http://dx.doi.org/10.1080/03075078712331378062.

Ramsden, Paul. 2003. Learning to teach in higher education. Abington, Oxon: RoutlegeFalmer.

Ryder, John. 1987. "Person perception in post-secondary education". The Vocational Aspect of Education 39 (104): 81-93. Accessed April 27, 2015. Doi: 10. 1080/ 10408347308002941.

Sánchez, Aurelio Villa, Ruiz, Manuel Poblete, Olalla, Ana García, Mora, Gonzalo Mora, Paredes, José Antonio Marin, Otero, José Moya, San Ildefonso, Isabel Muñoz, and Eizaguirre, Josu Solabarrieta. Competence-based Learning: A Proposal for the Assessment of Generic Competences. Bilbao: University of Deusto, 2008.

Suchanova, Jelena; Šliogerienè, Jolita; Mockienè, Liudmila. 2017. "A paradigm shift in teaching business English vocabulary". Journal of Teaching English for Specific and Academic Purposes 5 (2): 247-257.

Šliogerienè, Jolita. 2013. "Development of self-regulation at university studies". Coactivity: Philology, Education 21 (2): 162-169.

Šliogeriené, Jolita. 2012. "Students' reflection analysis in portfolio-based learning". Coactivity: Philology, Education 20 (1): 98-105.

Šliogeriene, Jolita. 2016. "Using portfolios to enhance self-regulated learning". Sustainable Multilingualism 9: 186-204. 